\title{
Ways of Seeing, Ways of Being and Ways of Knowing in the Inner-City: exploring sense of place through visual tours
}

\begin{abstract}
This paper presents an innovative insight into the complexities of the ways in which sense of place can be expressed and experienced. It particularly focuses on the phenomenological rapport participants have to the physicality of place and how it impacts on their ways of being, ways of seeing and on the construction of a sense of place (ways of knowing). In doing so it makes a case for conducting visual tours. Here I present the methodological framework that structured this approach and I give examples of how it can work. The narrative of this paper is constructed around three accounts of three different visual tours that were conducted in inner-city Nottingham. I argue that visual tours result in the combination of four types of intersecting narratives that give extra dimensions to the process of exploring ways of seeing and ways of being in the city:
\end{abstract}

1. the narrative of walking,

2. the visual narrative,

3. the narrative of the conversation in-situ

4. and finally the narrative of the written account by the researcher.

All of these narratives are constitutive and constructive of a sense of place.

In the case of my research on British Asian suburbanisation in Nottingham, these intersecting narratives brought to light a series of points on ways of seeing and ways of being and overall on ways of knowing the city. It highlighted a sense of place constructed around paradoxes, dichotomies and overall contrasted visions of the inner city where participants used to live and the suburbs of desirable housing where they now live. These kinds of observations are essential in understanding the way mobility and movements operate in the 'multicultural city'.

Key Words: sense of place; narratives; visual tours; walking; photographs 


\section{Introduction}

As I was researching British Asian suburbanisation, I needed to understand better my participants' ways of being and ways of seeing in the city to get a better knowledge of where they decide to live and why and the ways in which they negotiate the city. Inspired by Phillips et al.'s (2007) observation highlighting a '(...) lack of well grounded research into how British Asians perceive and make sense of the cities and the spaces in which they are living, and through which they are being enjoined to disperse' (Phillips et al., 2007 p218), I aimed to add to a growing body of knowledge on British Asians' urban dispersals by really focusing on the lived and embodied experience of place. To understand better the reasons behind but also the way suburbanisation took place, I needed to explore the way the city was on the whole perceived as well as negotiated; what was my participants' sense of place and how was it expressed in their negotiation of the city? As a frame of reference, I have used Massey's (1993) take on the notions of place and sense of place that should be conceptualised as dynamic with no fixed or pre-given 'single essential identities' (Massey 1993, p65).

In dealing with these questions, I wanted to explore new ways of conducting sociological research and collecting data: re-envisaging ways of doing sociology mainly thanks to the utilisation of a variety of methods and media that broadens the scope of our visions and our points of views of the world as well as of how we experience the world. This sociology embraces a sociological imagination advocated by Back (2007) who encourages us to have 'an imaginative engagement with the social world, utilizing a range of media, verbal and non-verbal forms of representation' (Back 2007, p7). With this in mind, I proceeded on designing a methodology that would include visual tours.

Similar kinds of methodologies have informed the design of the visual tours. ToliaKelly (2004a; 2004b; 2004c) and Back (1991;2005) have both used mobile visual methodologies in innovative ways. Back (2005) notably used a multimedia methodology to engage with the 'multicultural city' and questions of home and belonging (Back, 2005, p. 
21). The methodology of the visual tour combines both the act of photographing by the participants themselves as in the work of Back (2005) and the direct interaction between researcher and researched existing in the process of touring as in Tolia-Kelly's work (2004a; 2004b). As such, the work of Pink (2008; 2007; 2004), as an advocate of 'walking with' ethnography, has also been extremely influential. What these works have demonstrated is the potential for an alternative way of exploring sense of place in direct interaction with the place in which people live and engage with others or what Vergunst (2010) has named the 'immediacy of experience' to talk about 'the experiencing subject emplaced within its environment' (Vergunst, 2010, p376). This kind of phenomenological reflection on the experience of place was essential in the conceptualisation and conduction of the tours.

In this paper, I first elaborate on what I mean by visual tours and how they were conducted. Then, I draw a framework that develops from the importance of considering the phenomenological rapport to the city as place to the methodological and theoretical stress on the act of walking and 'walking with'. This form of 'walking with' ethnography is textually translated in the words of the conversation in-situ between the researcher and the participant as well as in the photographs taken during the walk. I argue for a theoretical rationale that considers four levels of narrativisation of place. I consider that the photographs as well as the conversation in situ constitute a narrative, which as constructed reality forms a story revealing of a social reality (Franzosi, 1998, p520; p548). Narratives can take a variety of storied forms (Barthes, 1977, p79; Riessman, 2005). Participants are given the opportunity to tell their story through words as visual signs; what they chose to photograph and in which manner (Knowles, 2006; p523). We will discuss further the potential of combining the two in the exploration of sense of place. I will also explain how I not only consider the visual narrative and the oral narrative of the conversation in-situ and while walking, but also regard walking as a form of narrative. Furthermore, I insist on the importance of always taking into account the narrative produced by the researcher as also constitutive and constructive of a sense of place. In the third section, I discuss the examples of three of the visual tours I 
conducted in the city of Nottingham with British born participants: Dalip, Parminder and Kulvinder (these are pseudonyms).

All three participants had suburbanised in the few years preceding the interview. For the purpose of this paper and to keep the argument focused and cohesive, I concentrate on aspects of the tours that took place in the inner-city only. With the focus being put on perceptions of the inner-city, we are able to see in the narratives how the inner-city is contrasted with the suburbs. I discuss this contrast in the section that concludes the paper. The originality of this paper lies in the fact that the main focus is on the rapport to the physicality of place in the expression of sense of place. Each narrative is different but they all present a reflection on the physicality of place: for instance the streets, the playgrounds and the terraced houses. This reflection is revealing of their perceptions but also of their experience of place.

\section{The visual tour in practice:}

In this section, I want to give a general description of the way the tours took place for the reader to get a better sense of this kind of participatory visual research (Bendiner-Viani 2005; Fink 2012) resulting in participant produced data. It was not intended to use the visual data for elicitation purposes. The photographs are a visual expression that like the conversation in situ are emplaced in time and space. The following sections will further develop on the methodological and theoretical framework within which they were produced and analysed. For the visual tours, I gave the participants a digital camera and I asked them to walk with me around their home, their neighbourhood and their former place of residency in the inner-city. The idea of touring the homes of the participants, as well as the streets, was inspired by the work of both Pink (2004) and Tolia-Kelly (2004a; 2004b) but this aspect of the 
research, focused on the domestic materiality of everyday life, will not be covered in this paper.

Initially, I gave very general instructions and asked the participants, who had agreed to do the visual tours, to take me around their homes and to places in the city where they currently lived or had lived; where they felt comfortable or not; or places which had particular meanings in their life stories. In essence, the participants led the tour; they chose the places we visited, what to photograph and how this should be done. In parenthesis, I must mention that I had previously introduced the participants to the technicalities of the digital camera (however purchased for its relative simplicity) as advised by Banks (2007, p82).

I conducted 5 visual tours in total. The tours were part of wider project and followed an in-depth semi-structured interview that took place in the homes of the participants. There are many reasons for which I did not want to make the tours compulsory. First of all, I wanted the tours to take place once a relationship of trust and collaboration had been established (Wiles et al., 2012, p3). The three tours that I have chosen to discuss in this paper were extremely rich in terms of their engagement with the inner city. It might be due to the fact that all three participants were younger than the other two and as a result more inclined to partake in this kind of exercise. The older participants were more inclined to tour their home. Besides being more comfortable with this kind of methodology, it might also be due to the fact that overall second generations tended to express good memories of the inner-city of their childhood. As such, they were more eager to go back to these areas. Above of all, I wanted the participants to feel entirely comfortable and free to decide how they wanted things to be done. In this manner only, the methodology holds the merits of being empowering even though we cannot dismiss the ethical issues that are raised in doing visual research. 
In publishing images, there is the potent question of maintaining anonymity. I believe the question to be as valid as when publishing quotations but images particularly convey this sense of exposure (Wiles et al., 2008). The photographs taken by the participants do not display people principally because they were really focused on the physicality of the place. However, as I am engaging with the question of place and sense of place in a specific locality that has openly been named I am aware that places can be identified as they are visually represented in the pictures reproduced here. In the spirit of 'locally produced knowledge' providing a “"thick description"” (Fink, 2012, pp45-46), it was thought to be important in the knowledge production of a sense of place in Nottingham inner city that not all identifiers be removed. Otherwise, the narratives would lack the necessary substance to understand better sense of place as a phenomenological engagement with the physicality of a particular place. Only, the most recognisable elements in the pictures have been blurred such as house numbers and names of street. I also believe that the researcher should make a responsible and respectful judgement as to what photographs and quotations should be included or not in the final account.

Furthermore, all participants agreed to sign a consent form professionally drafted and establishing that they gave their accord to the dissemination of their photographs in the thesis and other of the researcher's publications. As the authors of the photographs the participants retained the copyright. I took the stance that it was important for them to do so in keeping with the idea of empowerment in participant produced data. However, there is of course a difference between legality and ethics and ethical approval. Wiles et al (2008) remind us that it is not always sufficient to only consider the legality side of doing visual research. Because I had established 'good collaborative relationships' (Wiles et al. 2008, p) with the participants who took part, I have involved them throughout the process of writing and publishing this paper and ensured they understood that the images will be disseminated in a publically accessible journal. 
The entire conversation that we had during the tour was digitally recorded and then fully transcribed. I also sequenced the photographs with the transcripts to match the exact moment they were taken during the conversation. I did not have a set of questions and the conversation during the tour was spontaneous. The tours lasted for a few hours and sometimes had to take place over two days. During the tours, the participants regularly stopped at landmark places where they photographed and discussed at length of these places and the ways in which they mattered in their life stories. Dalip had established before starting that he was going to retrace the steps of his school run. However, for Parminder and Kulvinder, in some respects, it worked as a stream of consciousness. There was no predetermined or planned routes and I was spontaneously taken from one place to another, from one playground to a school gate, from one door threshold to a car park as they rediscovered places and made me discover them too.

\section{Methodological Framework}

This section situates my approach of the visual tours in relation to phenomenological ethnography, the importance of walking in this kind of methodologies and visual research.

\section{1/Phenomenology}

Exploring the relationship between participants' sense of place and the way they negotiate their ways of being in the city is at the centre of this methodology. It was thus essential to consider the experience of the city through the body and as such this approach called for a phenomenological engagement with place:

'According to phenomenology, the concept of place must be considered not only as a mental or social construct but as the sensuous experience of being in 
space and time, an experience linked to different practices of 'being in the world"' (Grasseni 2009, p8).

Akin to Merleau-Ponty, Casey (1996), for whom the study of place necessarily implies a phenomenological consideration, argues that 'the experience of perceiving (...) requires a corporeal subject who lives in place through perception' (Casey 1996, p22; original italics). We cannot simply look at representations of the city but we must also engage with experiences and perceptions through the body of the city:

'Basic to local knowledge, therefore, is knowledge of place by means of the body: (...). Bodies not only perceive but know places' (Casey 1996, p35; original italics).

In turn, knowledge of place is conveyed through the expression and the representation of lived and embodied experiences. Departing from this assumption, I argue that one of the key experiences of embodying the city is through the act of walking and as such it is also essential to consider the narrative function of walking.

\section{2/Walking as narrative:}

We have established that this methodology addresses the encounter with the city as phenomenological as well as discursive. In this, it recognises 'bodily motion pertinent to place' (Casey 1996, p23) and the importance of walking in the everyday experience of the city. This paper develops on the potential of conducting visual tours to better comprehend not only people's representations and perceptions of the city but also, to use Certeau's (1984) expression, 'ways of operating' (Certeau 1984, p100) in the process of 'walking the city' (Certeau 1984, pp91-114). For Certeau (1984), 'walking the city' corresponds to tactics of subversion to the established and strategic urban order. Without going into a detailed analysis of Certeau's considerations of 'walking the city' and the relation of the parts to the whole, we must mention how Certeau (1984) also talks of the city in the way it is appropriated and more generally negotiated beyond its characteristic as 'a totalizing and almost mythical landmark for 
socio-economic and political strategies (...)' (Certeau 1984, p95). Indeed, I want to retain Certeau's point on walking as a narrative. He talked of 'a rhetoric of walking' (Certeau 1984, p100) and described walking as 'a space of enunciation' (Certeau 1984, p98):

'The act of walking is to the urban system what the speech act is to language or to the statement uttered. At the most elementary level, it has a triple "enunciative" function: it is a process of appropriation of the topographical system on the part of the pedestrian (just as the speaker appropriates and takes on language); it is a spatial acting-out of the place (just as speech act is an acoustic acting out of language); and it implies relations among differentiated positions, that is, among pragmatic "contract" in the form of movements (just as verbal enunciation is an "allocution", "posits another opposite" the speaker puts contracts between interlocutors into action). It thus seems possible to give a preliminary definition of walking as a space of enunciation (Certeau 1984, pp97-98; original italics).

The first two levels particularly echo Casey's (1996) point aforementioned on embodied knowledge of place, but Certeau's (1984) first two 'enunciative functions' also have an added hint of agency implied in the notion of appropriation. Looking at the narrative content in/of walking, I will highlight some interesting information regarding the relation to the urban space, the ways of seeing but also the ways of being (see discussion in the last section) of my participants. As such, I will discuss not only the way the city is perceived but also appropriated and negotiated. Having established the importance of walking in the way the city is embodied and narrated as researchers we must then 'walk with':

'To participate is not to walk into but walk with-(...)' (Lee and Ingold 2006, p67). 
3/ The importance 'walking with'

By 'walking with', the ethnographer is equally confronted with the physicality (visually and with our whole body) of the place. As ethnographers, we are thus invited to share, to experience and to embody the physicality and multisensoriality of the field though the act of walking. Lee and Ingold (2006) talk of 'the sociability of walking' (Lee and Ingold 2006, p69). In line with Lee and Ingold (2006), Pink (2007) has been a proponent of 'walking with' in ethnographic fieldwork as a way to ““shared” corporeal experiences' (Pink 2007, p244). 'Walking with' as argued by Pink (2007) offers a phenomenological and sensorial engagement with participants' place:

'Social anthropologists are also increasingly seeing place itself as a sensory phenomenon (e.g. Feld and Basso 1996) and a focus on the phenomenological and sensorial aspects of place suggests that such constitution of place through walking is also a multi-sensory activity' (Pink 2007, p244).

The researcher is offered an opportunity to move around the place inhabited by the participants and thus, physically and sensorially glide into the narratives of their lived experiences. In visual research, there have been some inspiring and insightful pieces of research engaging with sensorial aspects of place (Pink 2007, 2008; Mackley and Pink 2012; Muir and Mason, 2012; Vergunst 2010). However, I wanted to particularly focus on the physical aspect of place, the physical specificities of different urban layouts and their importance in the expression of a sense of place.

In gaining a sense of place, the researcher is somatically confronted with the physicality of place and made aware of how it matters in the everyday lived experience of place through one, a process of empathy according to Pink (2007) and two, what Grasseni (2009) calls ‘legitimate peripheral participation’ (Grasseni 2009, p86): 
، "Legitimate peripheral participation" may thus stand also for a process of enskilment of the sense that the ethnographer undergoes during fieldwork. The ethnographer is effectively trying to share the same lived experience from 'adjacent' position' (Grasseni 2009, p86).

However, our position is not simply adjacent, especially in the case of the visual tours because meaning-making and place-making (Pink 2007, p248; on 'walking with video') are also being created out of the visual tour situation. In the narratives of the tours, I regularly reflect on my positionality in the field and on the particularities of this experience as I consider the question of ethnographic place-making (Pink 2008) in the process of researching places. In line with Ingold (2007), Pink (2008) argues that as ethnographers ' $(\ldots)$ we are entangled in place-making processes (...)' (Pink 2008, p179). Therefore, Pink (2008) insightfully insists on the idea of place-making and the multi-sensorial practice of walking as 'ethnographic knowledge' (Pink 2008, p180) that is produced through the routes and paths that we take with the participants (Lee and Ingold 2006, pp74-78). I want to additionally suggest that place-making also happens at the level of narratives: the ones constructed by the participants through the routes they take; the narratives of the visual production as well as the conversation insitu; the narratives constructed by the researcher in the final account. In relation to the latter, it is essential to be reflective of our own identity as researcher and of our position in the field. Elliott (2005) reminds us that "with a few notable exceptions, [reflexivity] is more often emphasized in the context of the collection of data and the relationship of the interviewer to the respondents than in relation to data analysis, interpretation or the 'writing up' of results' (Elliott, 2005, p154). It is important to remain aware throughout the research process that 'our own research narratives are also constructed' (Elliott, 2005, p154). I have made deliberate choices in the way I constructed the three narratives that compose this paper. One of the choices I made was to present each narrative individually rather than thematically. My intention was 
to maintain a kind of unity in the narrative despite my analytical intervention. All three narratives have a thematic concordance that I discuss in the concluding discussion. I tell a story that is derived from the oral and visual narratives that the participants have shared with me. The end result is not the same as the original narrative that was delivered to me during the tours. But running the risk of " "unfettered reflexivity"” (Elliott, 2005, p. 155), I did not want my voice to be overwhelming and it only comes through in brief intermittences when my own experience of walking with them helps me make sense of their sense of place. In the end, I have produced the final narrative of this sense of place as I have analysed it in the visual and oral narratives of my participants but also as I have experienced it through the act of 'walking with' and sharing the same 'visual field' (Lee and Ingold, 2006, p80). We now turn to the conversation and the visual production in-situ.

\section{4/The importance of talking and simultaneously photographing in-situ}

The interaction between researcher and researched, induced by the 'sociability of walking' (Lee and Ingold 2006, p79), engender a unique conversation in-situ. To paraphrase Lee and Ingold (2006), the process of walking alongside the participants in the same direction and sharing the same 'visual field' (Lee and Ingold 2006, p80) and 'walking rhythm' (Lee and Ingold 2006, p81) is less confrontational than the face-toface interview setting. As such, the camera acts as a medium of representations of this 'visual field' (Lee and Ingold 2006, p80). The methodology brings out these encounters, in a textual form, in the language of words as well as photographs. As previously mentioned, the conversation during the tour was recorded and then analysed in relation to the participant-produced photographs.

Photographs as ‘sign-vehicles' (Radley 2010) and as a 'creative process requiring the same kinds of conceptualization as a written text' (Knowles 2006, p513) are treated as 'staged' meaning with a language of their own in the act of representations. 
The expression 'visual staging' refers to the constructed nature of photographs acknowledging a certain mise-en-scene in their creation. Knowles (2006) explains that:

'The photographs are staged in the sense that they are structured by what can be photographed in environmental portraiture - people, places and things and the connections between them - and by elements of theorization embedded in their staging, the idea that race/ethnicity is in the fabric of intimate relationships between people and places' (Knowles 2006, p523).

Overall, if we consider staging as discursive and seeing as cognitive, we can argue that the staging (as in the composition, choice of subject, framing, angle, etc.) is the materialisation, the discursive act of the cognitive act of seeing (See Knowles, 2006). Knowles (2006) also argues that: 'Seeing and Photography are interconnected activities; but photography is a materialized manipulation of the (equally manipulated) cognitive processes involved in seeing' (Knowles 2006, p512).

This methodology represents a multi-textual expression of visual but also of phenomenological encounters with place that words alone cannot achieve. Keeping in mind these four pillars of the theoretical and methodological framework, I will now proceed to narrate three of the visual tours that I conducted in Nottingham.

\section{The Narratives of Three Visual Tours}

Dalip

Dalip was a 45-year-old Nottingham born Sikh man. His parents, who came from the Punjab, settled in the inner-city area of Hyson Green in the 1960s. He regularly comes back to Hyson Green to visit them. His connections with the area and his family, with whom I spent a lot of time, took the fieldwork from the inner-city of 
his childhood to his present home in rural England. He used the first half of the visual tour to retrace the steps of his 'school run' and the second half to tour his home and neighbourhood. Kulvinder, Parminder and Dalip all chose to start the tour outside their childhood homes. From there, they all took the tour further and further afield. At the start of the tour, Dalip took the following two pictures while reflecting on the change in the physical geography of the street where he grew up and how, for him, it socially impacted on the local community:

In this community here, on this ... Road, there was a sense of community, you know the people that were living here already, then the Asian ethnic community moved in here, Irish people that lived in here. And we had this road and this road connected us all and then without any discussion, with the people that lived here, suddenly the community was cut in half. Here, all from here onwards, all these houses, all the people that we knew who lived here, without discussion, was cut in half.

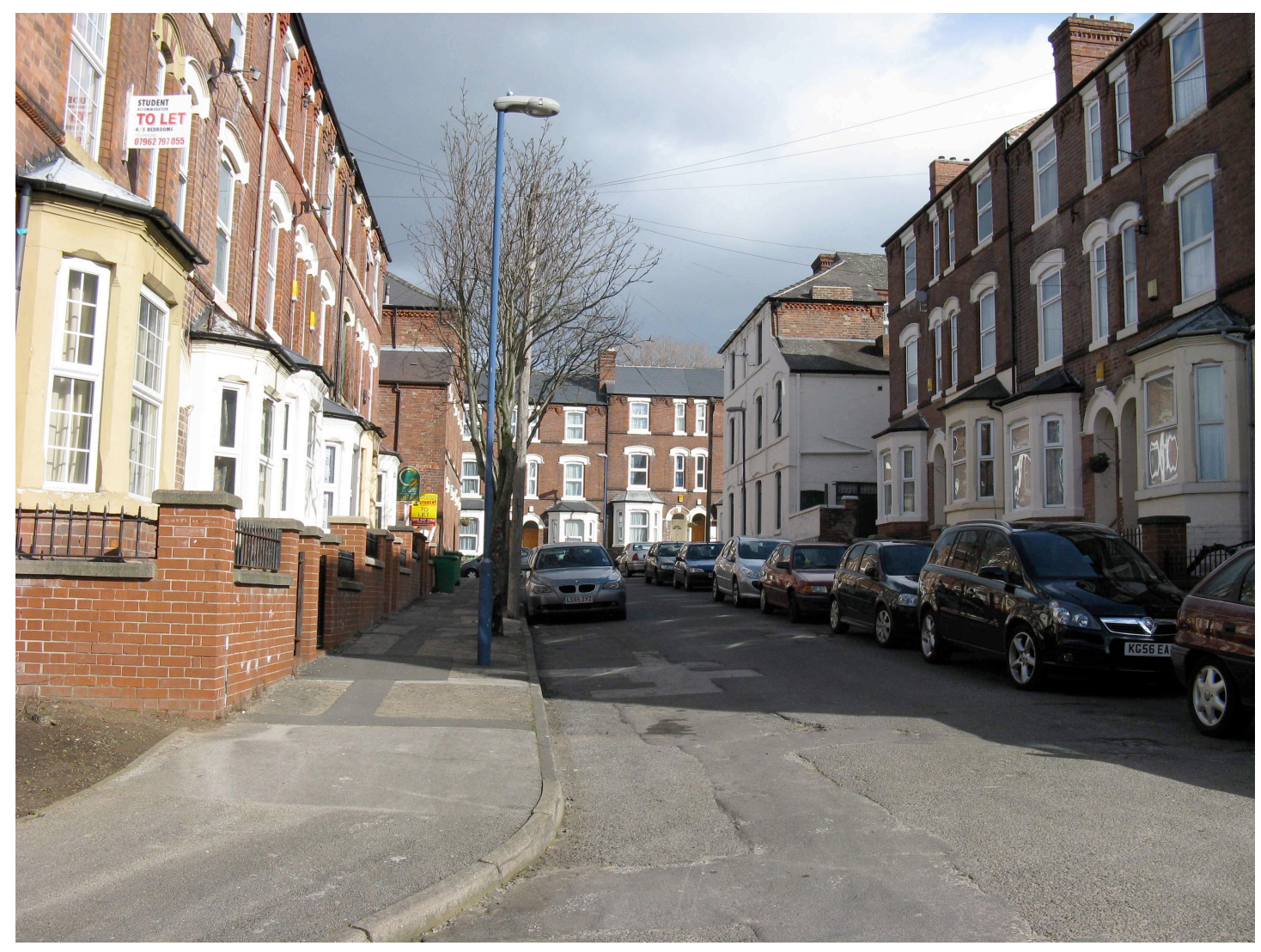

Figure 1 


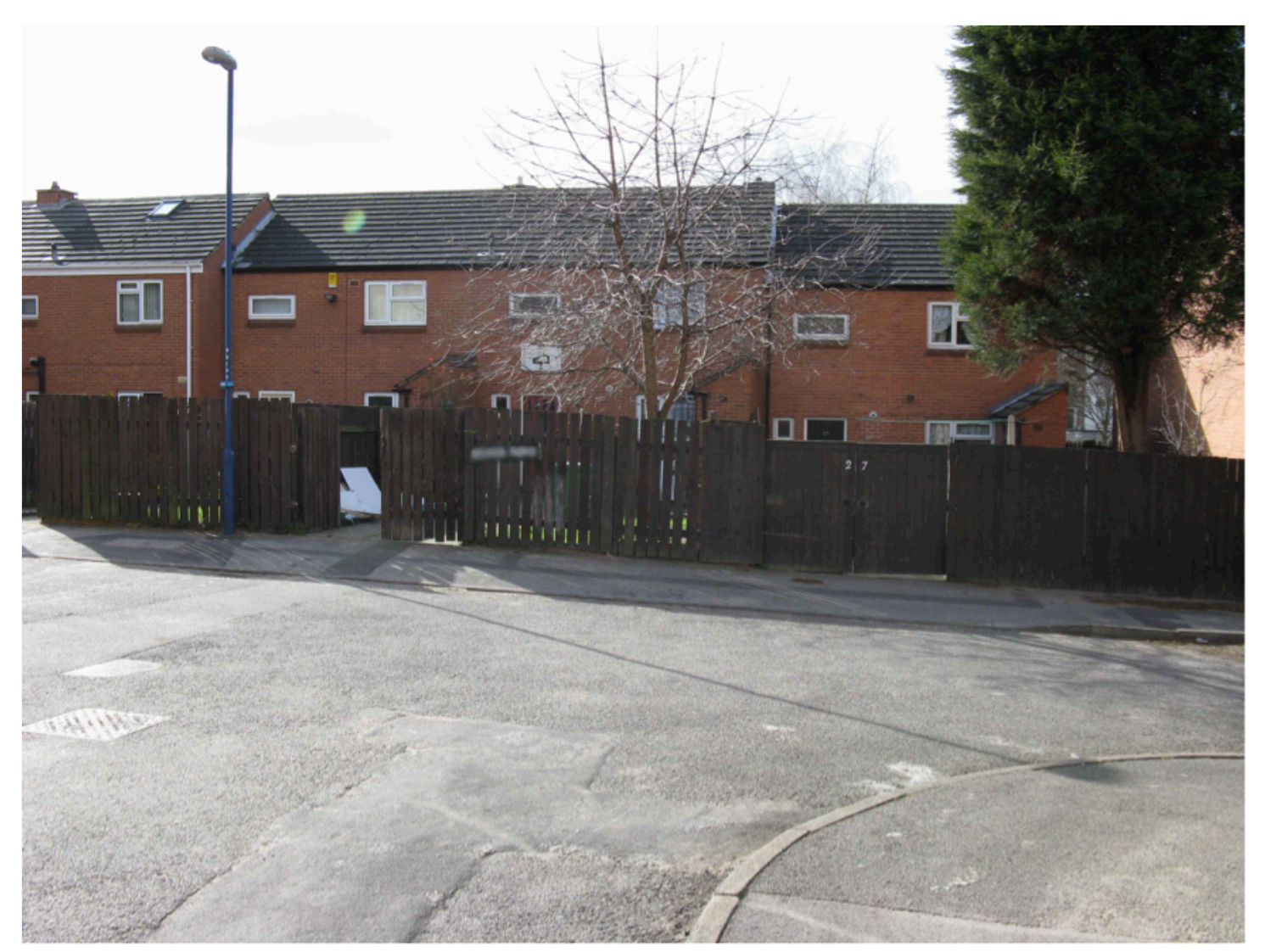

Figure 2

He explained that 'the community was cut in half' because of the construction of a row of council houses that had divided the street in half as shown in the second picture. It is implied here that their ways of being determined by inter-cultural exchanges and encounters was interrupted by the physical changes to the street. Suddenly, present and consequently future connections and exchanges were broken off and the dynamic of the street interrupted. The ways of being as reflected upon while walking and taking the pictures are starting to highlight ways of seeing the inner-city as a multi-ethnic community. Here the inner-city's physicality is first synonymous of the multi-ethnic city and eventually of the multicultural city where sense of place is expressed as a sense of belonging to a plural community and where the street is metonymic of the plural community. The street is where plurality meets and intercultural exchanges can happen. A physical alteration to the landscape had a heart felt impact because physical proximity assumed social proximity. This also denotes the topophilic (Tuan, 1974) ${ }^{\mathrm{i}}$ importance of the street in the everyday life of 
the inner-city and in defining the sense of place. Many participants have recalled this importance in their narratives. This is also stressed by the fact that the ones who did the tours all came back to the street where they grew up. Overall, they all stated that they enjoyed going back to these places that they did not often have the opportunities to return to, but with which they had a strong emotional attachment.

As the tour went on, Dalip also recalled the particular attention he had to take when walking his younger brothers to school in the 70s. He was especially wary of looking up in case 'people would throw things at [them] from the windows'. By reenacting the school run Dalip was corporeally reminded of the necessity of having to look up at the time. As I walking next him, he regularly looked up and pointed at the top of the houses helping me get a feel of this 'anticipatory watchfulness' (Bissell 2008, p52), and to use Pink's (2007) expression, it allowed me 'to learn empathetically about their experiences' (Pink 2007, p240) of walking to school and get a sense of their physical vulnerability. The visual tour with Dalip was especially important for the both of us to reflect on this issue. The fact that we revisited the school run through the visual tour represented a physical negotiation of the place that is inscribed in the body through memory. The tours were in parts used by the participants to go back to places where they used to live and may not have been navigated for a while. The tours and the interviews are inextricably linked to memory and as such, to the temporality as well as the spatiality of trajectories: the lived everyday and the memory of the everyday:

'Place is the generatrix for the collection, as well as recollection, of all that occurs in the lives of sentient beings, and even for the trajectories of inanimate things. Its power consists in gathering these lives and things, each with its own space and time, into one area of common engagement' (Casey 1996, p26). 
By re-enacting 'the school run', Dalip and I were both confronted with the physicality of the area, the danger that it represented at that time for three 'Asian kids' and the memories that are imprinted in the concrete of this landscape.

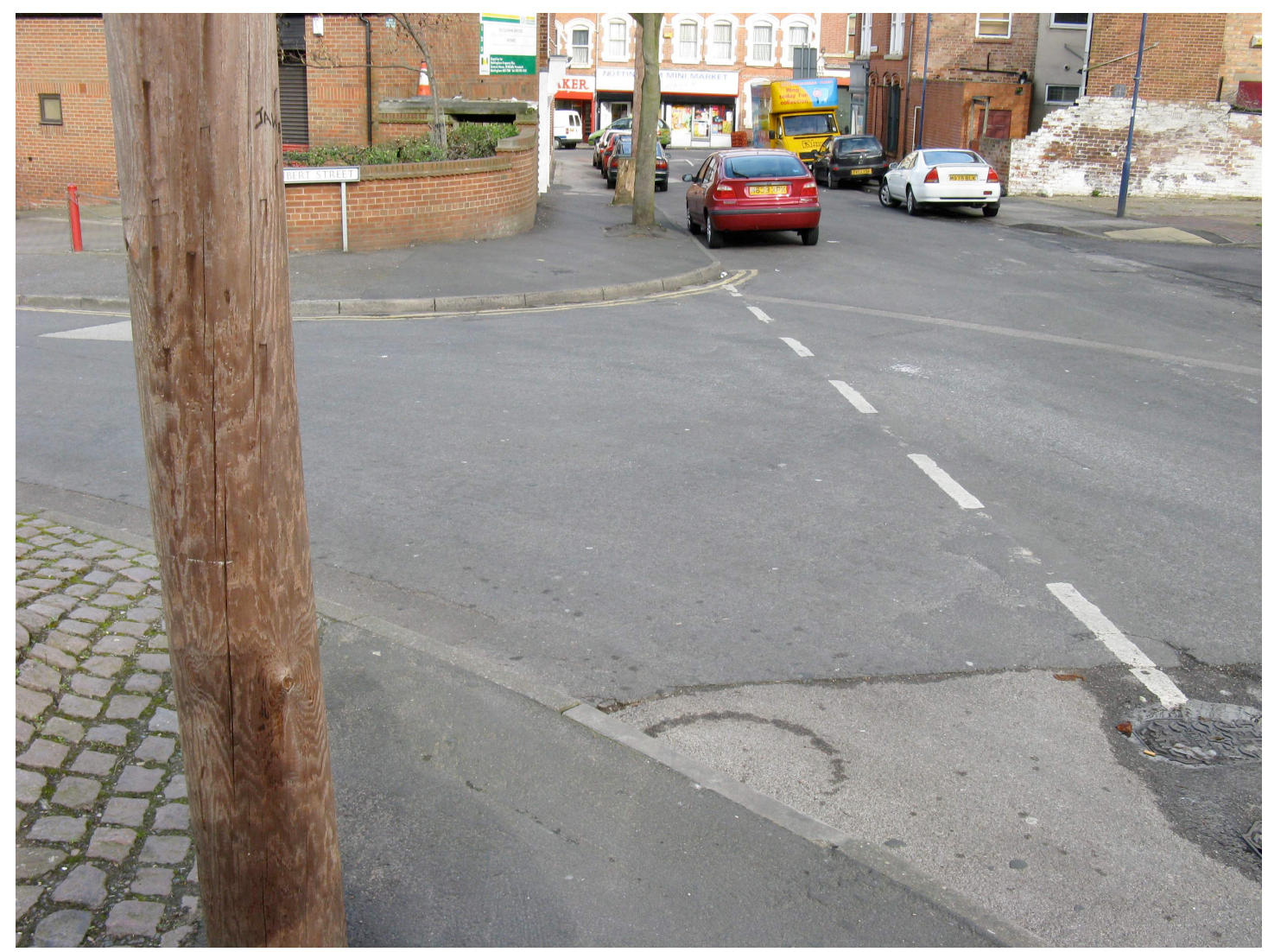

Figure 3

On this corner, on that curb, against that pole, Dalip was violently attacked on racist grounds. This incident was sufficiently significant for him to photograph the pole and the curb (at the forefront of the composition). Being the 'victims' of racism, of racist attitudes projected through words or even physical violence can be depicted with the powerful and direct effect that it implies. He visually and prominently framed a painful story that is emplaced and can be imagined from his point of view through the photographic frame. Paradoxically, he also has, as many have, described the inner-city as 'comfortable' - which is usually the predicated term to describe suburban living. These ambivalences and paradoxes can also be explained by the way he negotiated and altered his ways of being in different streets or blocks of streets in the same inner-city area and often according to the time of day or night. This was 
observable with all three participants. Many, despite the move to the suburbs, still refer to the inner-city of their childhood as home and notably for that same reason they feel 'comfortable' in this familiar place. However and as another paradox, Dalip always insisted on leaving the inner-city as the main drive to his success.

\section{Parminder}

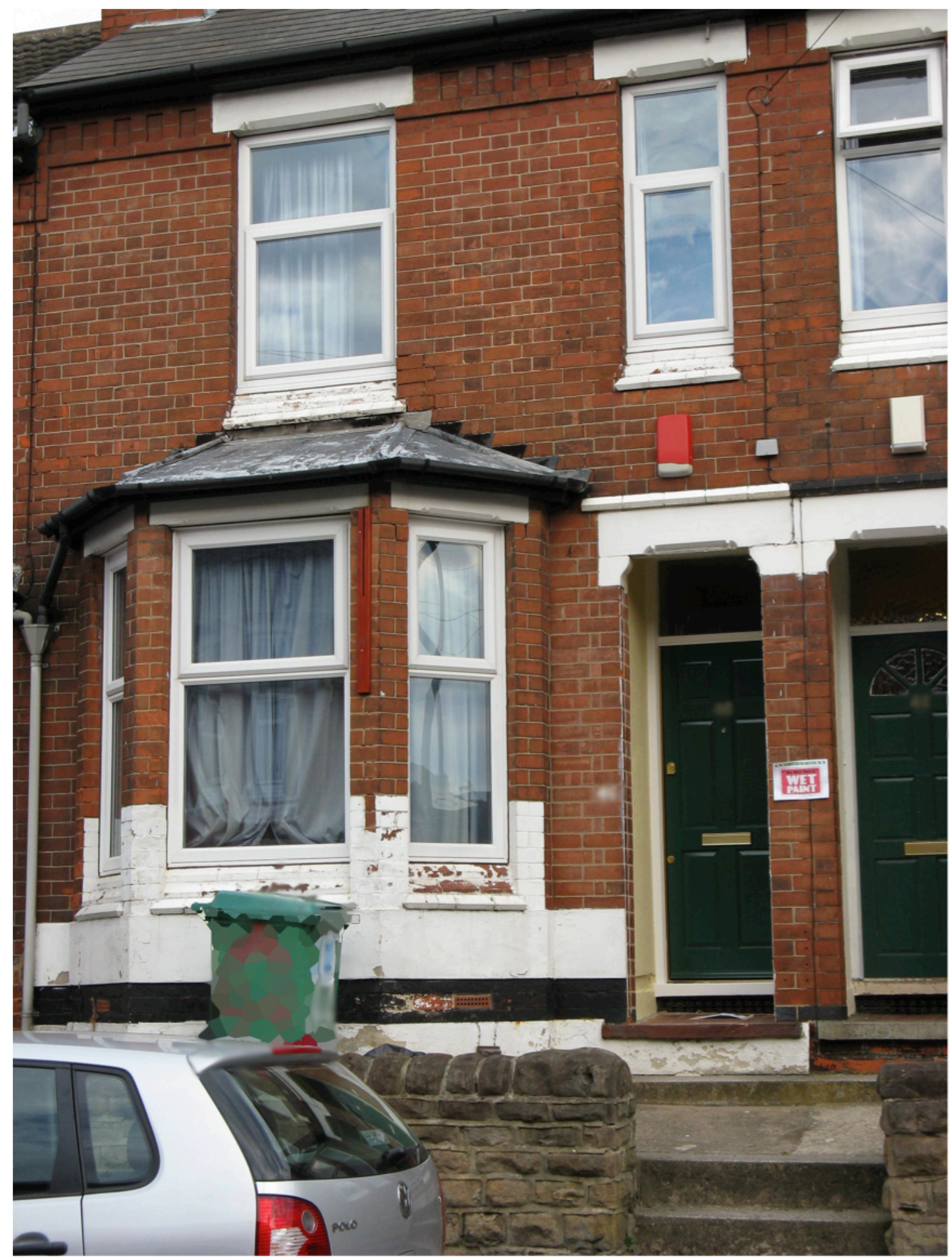

Figure 4 
This picture was taken on the tour with Parminder, a forty-year old Sikh woman. As in all three cases, we started the tour in the inner-city outside her childhood home before she walked me to other key sites of her everyday life at the time she lived in the Lenton area. While Parminder was taking the picture, here is how the conversation in-situ and relationally to the act of photographing in part went on:

$\mathrm{P}$ (arminder): Look how small this space is but we could get, we could get my god, my family, my cousins and all our friends just literally hanging out this little wall. They all used to be in a row.

M: Sitting there?

P: Yeah, all kids in a row, yeah.

The initial phenomenological and visual encounter to the street she grew up in translated in a close up of her house, and remembrance of the time spent outside on the wall: a liminal zone of observation and encounter in the landscape of the street. We will return to this aspect. She went on to take a second picture of the house, this time focusing on the front door. Her choice of composition was also explained by her concern to 'get a shot without the wheelie bin outside' which directly followed in the discussion her description of the area as 'a completely run down student area': 


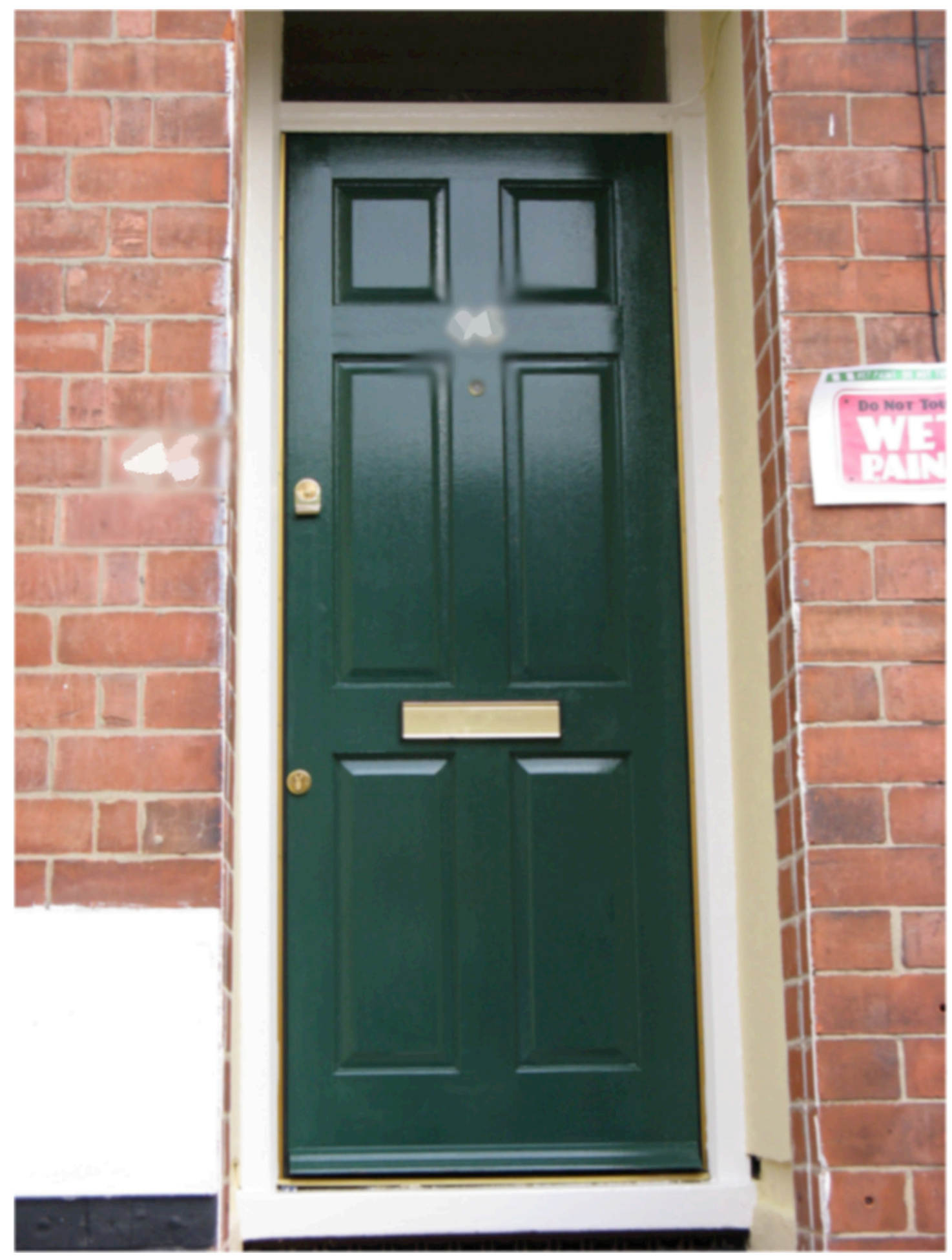

Figure 5

It looks horrible! I mean all the rubbish, all the, this was what we were cursing just before we left. There is no respect for this street but I've got very fond memories of being here (...). 
The choice of composition raised an important issue. It allowed her to talk about one of the motives she and her family had to leave the area that is nonetheless still associated with 'fond memories'.

As the conversation continued, she reflected further on who used to live on the street, mapping out an ethnic composition of the street:

I can't really tell how many houses must be on this road, must have been, yeah, at least, it was a combination of 20 , must have been 20 Sikh families, I'm quite sure because I know which houses they lived in and the rest were a combination of African Caribbean and Muslim families, umm, yeah, there were a definite multi-ethnic vibe.

The way she mapped out the street of her childhood, on many instances in the conversation in-situ, highlighted different points relative to her sense of place in the inner-city. Her sense of place but also her sense of self was local and diasporic. Parminder drew boundaries around the groups she expressed a sense of belonging to or not. Karner (2007) points out that:

'(...) the construction of 'in-groups' and 'out-groups' through the delineation of boundaries is a defining characteristic of all discourses of collective belonging, whether imposed by powerful outsiders or articulated by selfidentifying group members. Identity, whatever else we may mean by the term, involves the distinction of 'us' from 'them'” (Karner 2007, p32).

These groups are mostly those that compose the South Asian diaspora. Most interestingly though, her reflection on the local urban landscape of the inner-city and the proximity incurred by its physicality, more clearly outlines a sense of place as visibly multi-ethnic and eventually a sense of belonging to a multicultural, plural and diverse community even if she still draws boundaries around ethnic groupings:

Parminder: I think what I miss the most about being here was that I felt as I was part of a community and not just, I don't just mean Sikh community, I 
mean as a minority ethnic, we were visible, we had voices, we. Yeah, it was a vibrant community. It was really nice.

Parminder knew every corner of inner-city Lenton, from the Victorian streets to the dark garages and the precinct of the Lenton 1960s estate. Walking side by side with Parminder I was able to get a greater sense of place of the area. However quite familiar with the city, I had never quite explored some of its inner-city corners, mostly because they were outside my everyday paths but also because my ways of being in the city were preconditioned by social constructs of these areas. Our experience of place is indeed often 'constituted by cultural and social structures that sediment themselves into the deepest level of perception' (Casey 1996, p 18). It was an environment that I had imagined as other but had been home to my research participants and, as in the case of Parminder, felt particularly comfortable to roam around. It forced me to be physically confronted with the environment they so often talked about.

To mark the end of a long tour, Parminder walked me to the Gurdwara (Sikh temple) her mother usually attends in Lenton. As we were standing outside the gurdwara staring at the building and before being invited by the intrigued granthi for some desi cha and a chat, Parminder highlighted the importance of the gurdwara as part of the landscape of her city addressing a sense of belonging possible because of the identification with a landscape: one element amongst others in the construction of her identity as one of 'multicultural' Nottingham's inhabitants: 


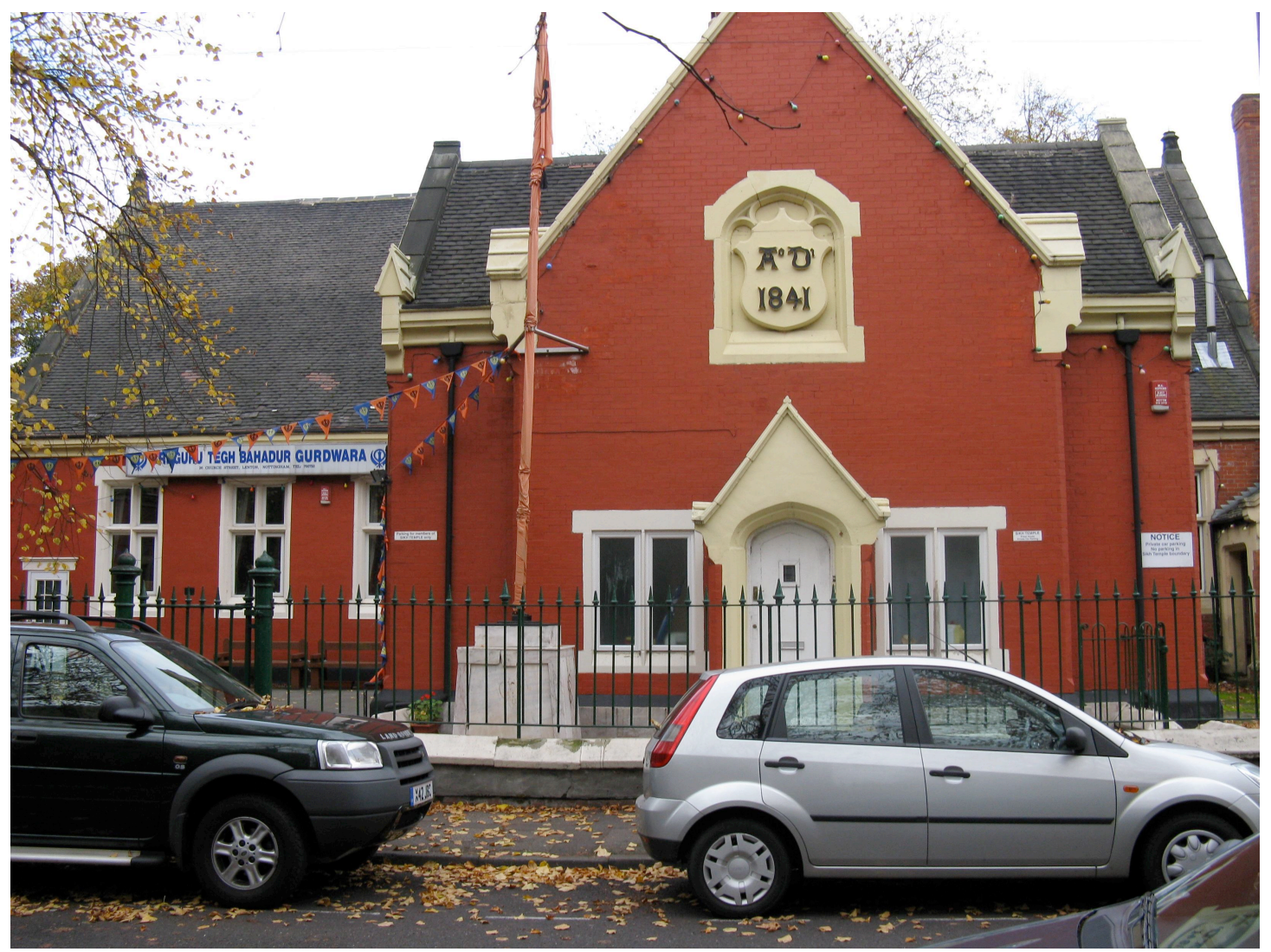

Figure 6

I think when I say that we sort of move out into suburbia, I'm feeling sort of a little isolated; I think to know that there is a place of worship on your door step is really, really important just for a sense of belonging even though I don't use this, just looking at it and knowing that it is a place of my faith and my people. It's a really nice feeling I suppose.

The idea of exploring ways of seeing is also intimately related to ways of being seen. This aspect notably relates to issues of visibility, which is negotiated differently in different spatial and temporal contexts. The bodily connection and the spatial embodiment of the social positioning notably surface when some refer to issues of visibility. Parminder went on to say:

But outside of that physically, there's very little ethnic minority visibility in Wollaton, for me, whereas in Lenton you could just look out of the window, I mean we lived in a very traditional Victorian terraced property. It just looks so small from outside which was one door, one window and then you open the 
door and it goes back! But we were surrounded by people, people of colour, which helped, which I think helped affirm my identity cause it always reminded me and I felt comfortable and I didn't stick out but, I mean for example we moved here, I think one of the neighbours said: “oh isn't it so nice to have an Asian family move into the street". And I thought "oh god do people still think like that?” Because I had just come from an all multicultural part of Nottingham and was completely comfortable with that, I didn't appreciate that we would stick out, that we would be the odd ones according to the street (...).

In her narratives, Parminder makes a clear connection between the inner-city house and its physical proximity to the multi-ethnic street. As in many other narratives, the window of the inner-city house is mentioned as a direct extension of the house on to the street: a liminal zone of interaction. Cieraad (1999) discussed the case of Dutch windows as performing a liminal function between the private and the public. In Parminder's case, the window allowed a constant visual and physical interaction with the diversity that constituted sameness and belonging in place-based identity. As we have previously discussed, Parminder made a similar point when she discussed the wall outside her house as a liminal zone of interaction. She embraces her lived embodiment of otherness shared by other 'people of colour' in the innercity, but contrasts it with the fact that she was, however somehow positively, recognised by one of her suburban neighbours as the 'stranger', the body out of place in the neighbourhood implied as homogenous (Ahmed 2000, p25): ways of being seen and the figure of the stranger as the perception of embodied otherness. In the following statement, Parminder described the differing physicality between the innercity and the suburb as a reason for the lack of interactions with the neighbours:

We kind of you know in our eye sight we've made visible contact with people directly in front of us, next door to us, outside of that I think it's a just a case, 
if we see them but that's what I mean people don't seat outside the front, it's not that kind of neighbourhood, where you seat out front whereas in our old property, there wasn't even a space to seat out front, but most people seemed to be on the street so.

In their interviews, all my participants mentioned the lack of neighbourly relationships in the suburbs mainly contained at the stage of distant visual interaction and cordial greetings.

\section{Kulvinder}

Like Dalip and Parminder, Kulvinder was Sikh and his parents came from the Punjab in the 60s. He grew up in inner-city Nottingham, in Hyson Green to be more precise. Like Parminder, he now resides in the leafy suburb of Wollaton. Being in his late twenties, he was however younger than Dalip and Parminder. During his interview and during the tour, Kulvinder often referred to the eventuality of being the 'victim' of petty crimes (most notably at the family's corner shop) or the witness of gang activities such as drug dealing. I use inverted comas around the word victim because Kulvinder would not have described himself as a victim. Instead, he often displayed a street-wise attitude to his life in the 'Green' and tended to play down the dangers. It was also important to him not to stereotype the inner-city:

I think people's perception of it was that, you know, crime-ridden, it has quite a large immigrant community as well and I think people have quite a bad perception of those areas anyway. It's got probably a higher than average crime rate and it's known for, you know, drug dealing and things like that but to be honest a lot of that when I was growing up as a kid, I mean I saw, you know, certain things and knew certain people knew what went on but it wasn't as bad as people make out to be, umm, and certainly, I think today, it's probably, you know, it's a lot better. 
The inner-city of my participants' childhood can sometimes be romanticised, idealised but also, as we have discussed with Dalip, the background to more difficult accounts of everyday negotiations of racism and other risks assessments. Negotiating the 'metropolitan paradox' (Back 1996, pp7-26) in the inner-city was also congruent of a navigation of the place relative to other kinds of dangers or risks that it might represent: 'Yet the street is dangerous and desirable simultaneously, the site and material cause of intercommunity violence and the condition of possibility of intercultural identification' (Keith 2005, p103). Kulvinder took many precautions during the tour, being constantly bodily wary of his environment especially when he walked me to the back streets of Hyson Green. 


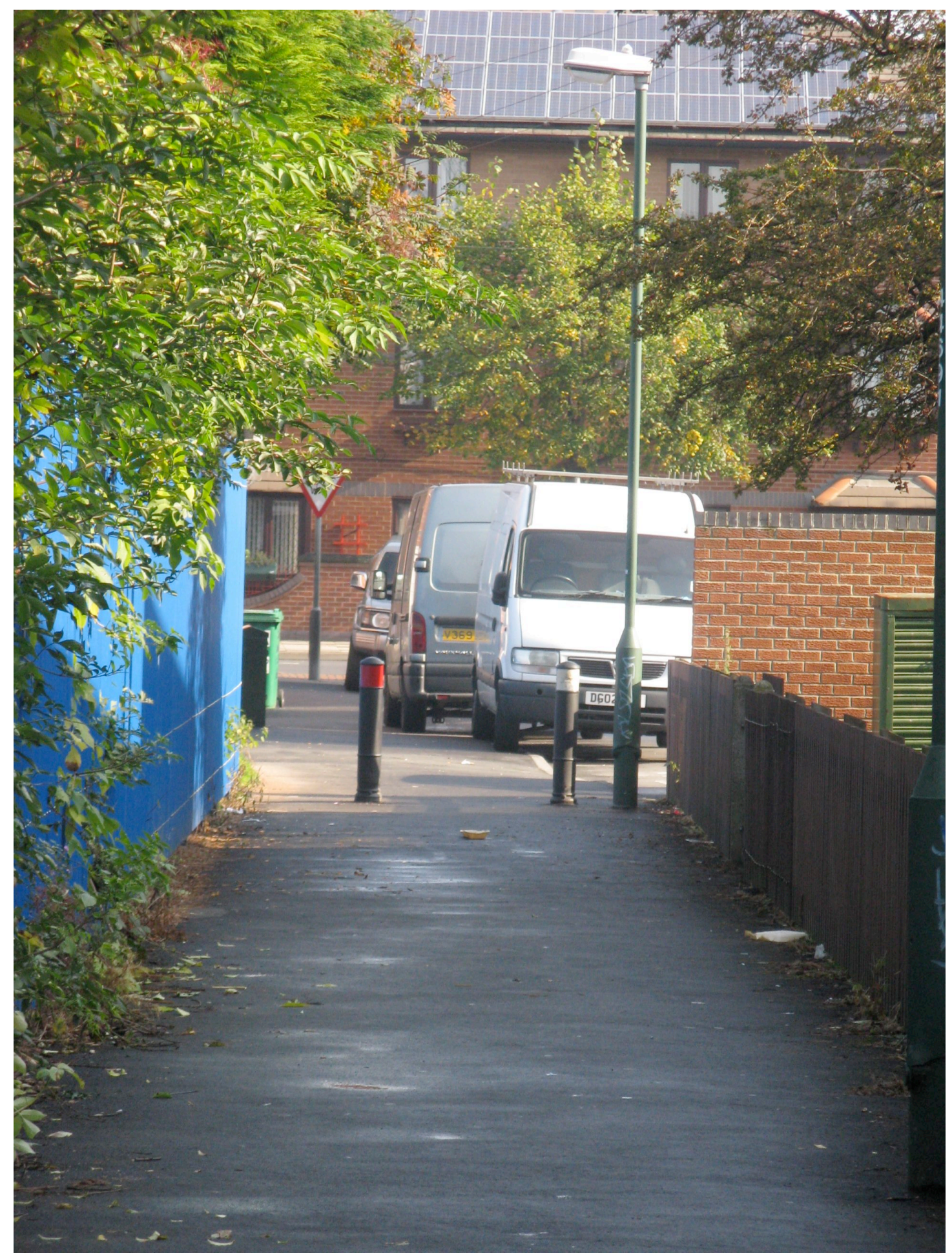

Figure 7

His gaze was furtive and constantly scanning what was happening around us. His attitude was characteristic of what Bissell (2008) describes as 'anticipatory watchfulness' (Bissell 2008, p52) and this observation illustrates how '[p]eople communicate through their posture in movement, involving their whole bodies' (Lee and Ingold 2006, p80). Although he was familiar with the place, I sensed he was 
particularly cautious especially as and because he was walking with me. The way we were walking around at a relative slow pace was admittedly conspicuous. Indeed in contrast with the buzzing Radford Road as the main commercial artery cutting across Hyson Green, the side streets were not experienced as places where people could leisurely stroll around. The differences in walking rhythms (Vergunst 2010) highlighted a physical contrast between the main streets and the side streets. He also took much care as to when and where he would take the camera out of his pocket and as to what he would photograph. Despite having to negotiate our paired positionality in place, I realised that it was important for him to show me those places which were part of his biography.

Overall, Kulvinder demonstrated in his interview and his visual tour a 'streetwise' attitude integral to the construction of his identity and his masculinity (in his narrative) measured against the habile negotiation of the place and giving out an apparent ease in his negotiation of that place. The streets, car parks, football and basketball grounds of the inner-city, that he walked me to, despite presenting some danger were also negotiated as spaces of freedom, friendships and sporting achievement. We notably finished the tour at two of these places that were decisive in the construction of his biography and that he had already mentioned in his interview. We first stopped outside the John Carroll Sport Centre in Radford where he used to come and trained with his basketball team. 


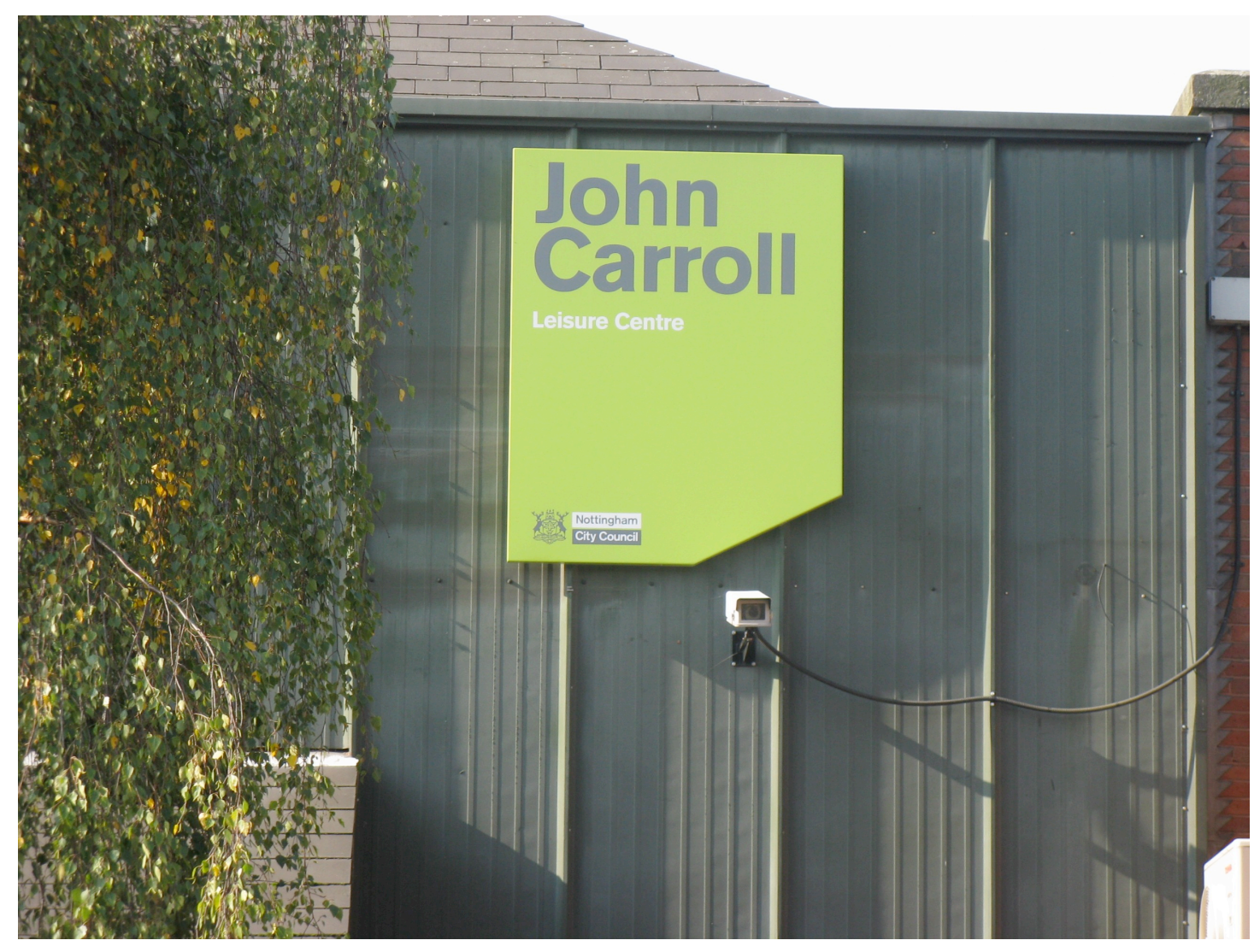

Figure 8

And we spent the remaining time of the walk outside a disused basketball ground where he recalled spending most of his free time practicing on his own (even late night or very early in the morning) or with other kids from the area. 


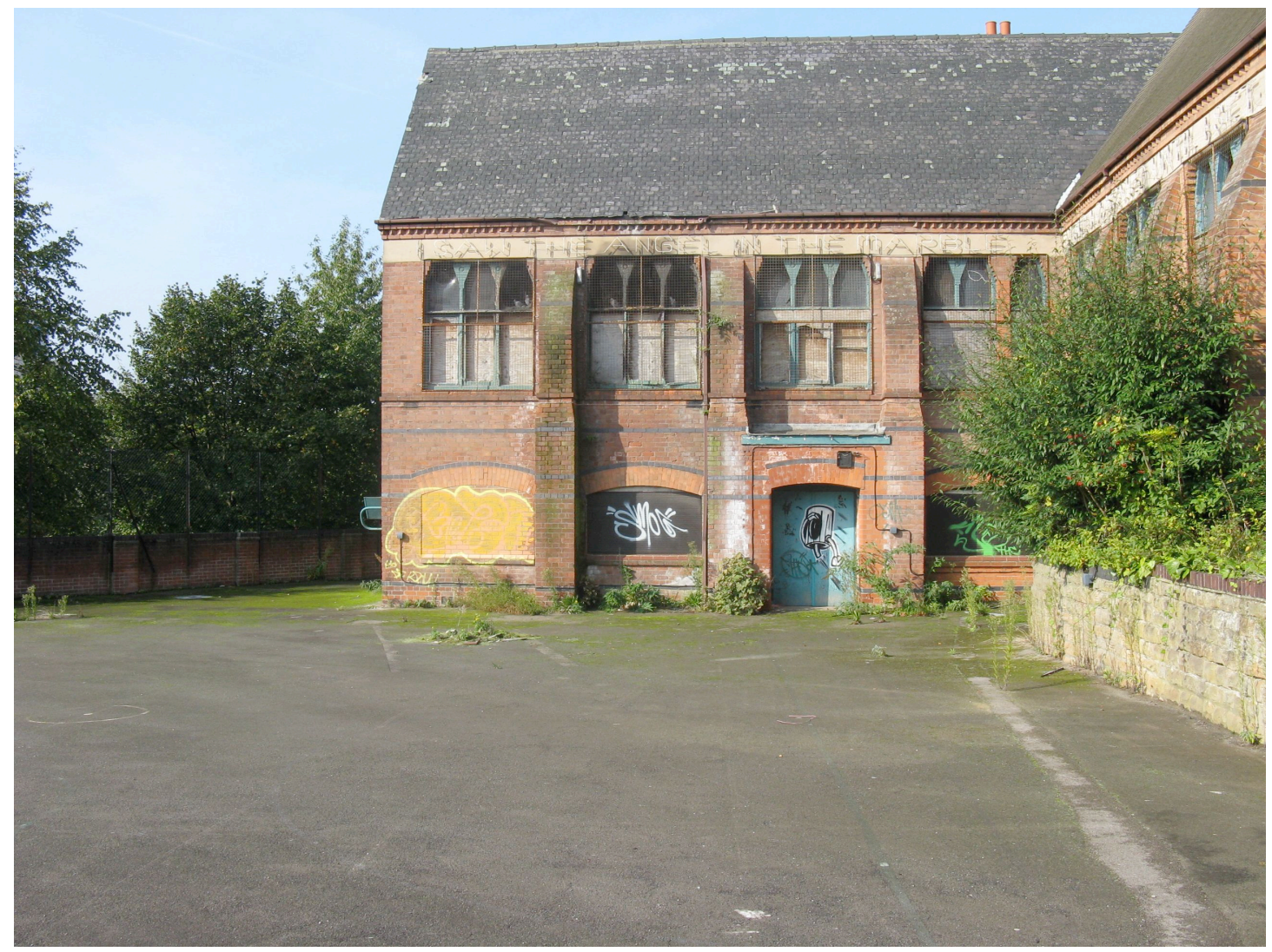

Figure 9

In contrast and just before we went to talk outside the John Caroll Sport Centre, we had a long conversation outside the public school situated in the Park Estate (a highly desirable private estate at the heart of Nottingham) that he used to attend in his early teens. We had often discussed his desire of buying a house in this area as his ultimate social achievement in the geography of the city. But as I was standing outside his former school and as he was expanding on his desires, these aspirations were emplaced. The tour showed me the contrast between his life in the inner-city living above the shop, playing and socially engaging in the streets of the inner-city and his attending a public school in a highly desirable neighbourhood. These were not contradictions but the multiplicity of his emplaced identity. That allowed him to confidently negotiate different places in the city but also to project himself in other places. 


\section{Discussion: Ways of Seeing and Ways of being in the Inner-City}

Combining mobility through a form of 'walking with' ethnography (Pink 2007) and visuality by asking participants to take photographs during the tour, visual tours are a unique way of experientially approaching ways of seeing, ways of being and ultimately ways of knowing.

During the visual tours, it appeared that the way the place is embodied and the 'corporeal being-in-the-world' (Bissel 2008, p44) were circumscribed by differing urban and suburban physicalities. Dalip and Parminder particularly perceived marked physical differences between suburbia and the inner-city. These differences had bearings on the way they embody the place around them and how it affected their social positioning. For instance, the inner-city was often depicted, in the language of words and photographs, as a place of proximity with your neighbours: physical and social proximity mostly incurred by the topography of terraced housing. Everyday life was constantly taking place on the background of the street. Furthermore, participants often mentioned feeling at greater ease in standing in the inner-city streets rather than in the streets of their suburban neighbourhood because of the possibility for greater visibility. This visibility was explained in relation to the multiculturality of the innercity environment.

Where, when and the way, (e.g. the care taken in not being conspicuous in certain areas) we walked, also represents a narrative which was especially telling of contrasts within the inner-city and of how these contrasts had been embodied by the participants. The tours with both Dalip and Kulvinder particularly highlighted embodied contrasts between certain streets that were deemed and experienced as safe and the others as unsafe. This prompted them to adapt their attitudes in tune with everyday negotiations of the place. This notably showed in the way they negotiated my presence during the tour. In a similar manner, walking with Parminder was also revealing of these contrasts. At some point she talked of 'the scummy end' in 
reference to Radford and in contrast to Lenton. She also pointed and shot at it. When she said that we were standing outside her former house and only one street was separating us from the 'scummy end' but we never walked beyond that point in the same way she avoided walking there when she lived in the area. As Certeau (1984) points out: 'In the framework of enunciation, the walker constitutes, in relation to his position both a near and a far, a here and a there' (Certeau 1984, p99). I was invited to share that positionality, walking with the participants and sometimes only by looking at, but not walking beyond or past some places. This helped me reflect on the paradoxes and the complexities of ways of being and ways of seeing and emplaced identities in the city. The last point further stresses the fact of place-making in the ethnographic act of visual touring and how my position in the field and eventually my voice is also constitutive of the narrative.

The conversation in-situ brings out narratives otherwise not possible if the participants were not somatically confronted with the place they attached to those narratives. Touring allows the participants to be confronted to a sensorial physicality acting out as madeleines did for Proust (Proust 1987, pp44-47) in triggering memories and consequently leads them to be reflective and self-reflective of their representations. We can most prominently see that with Dalip as he clearly retraced the steps of the school run, but also with Kulvinder and Parminder because they too went back on the paths of their childhood as they revisited landmark places in their biographies. With these paths being re-enacted, we realise how the place is made, constituted by the act of walking, by the routes and paths one takes and takes again.

In the visual tours, the staging of the photographs happens relationally to the conversation in-situ and as such adds an extra textual dimension to the participants' representations of the place. These representations are not just illustrations, but they also highlight positionality. Here, positionality in the inner-city is mostly contrasted to ways of seeing and ways of being in the suburbs. In the accounts, I have discussed the 
way the photographs were taken in relation to the conversation of course as well as the way they are composed, that is their language. I have argued for the importance of using photographs to explore ways of seeing through a phenomenological encounter with the city as place (ways of being). I am interested in the ways of seeing and ways of being as ways of knowing of my participants.

It is interesting that only one of the participants, who took part in the tours, visually engaged with the streets of the suburban space. When I questioned the other participants on this absence, they all mentioned a lack of affinity with the suburban landscape and a lifestyle centred on the 'privacy' of the home as their justification. These responses were already telling of a public/private dichotomy demarking ways of being in the city. In this dichotomy, the suburbs are constructed as the realm of privacy and home-centred family life and contrasted with inner-city street life and its intercultural interactions. In other words there are contrasted visions and narration of the inner-city in relation to the suburban, based on a dichotomous sense of place. Yet, this dichotomy is animated by the complexities and paradoxes of everyday multiculturalism (Wise and Velayutham 2009). In this paper, I have highlighted this dichotomy particularly in relation to the inner-city as a place of possible 'intercultural identification' (Keith 2005, p103) and yet also as a place where racism and other risks and tensions are always 'around the corner'.

In the current debate on multiculturalism and community cohesion, these are essential findings. What are the lived and embodied perceptions of a city in which people are '(...) being enjoined to disperse' to quote Phillips et al. (Phillips et al. 2007, p218) again? The suburbanisation of South Asian is increasing but cannot simply be seen as a one-way movement. Suburbanisation, as social and geographical mobility, was for most of the participants an obvious step even though the inner-city retained a certain attraction. Most of the participants had to regularly come back to the inner-city mainly for shopping and religious activities as well as visiting family 
members. Furthermore, suburbanising was not always experienced as a smooth and obvious transition. We have notably discussed the issue of visibility and the contrast being made between the sociality of the inner-city and that of the suburbs. Finally, some, like Dalip's parents, had made the conscious decision to stay in the inner-city. Another one of my participants decided to return to the inner-city after spending a few years in a leafy suburban area of Nottingham. The lifestyle in the suburbs was incompatible with their everyday life.

\section{Conclusion}

In the visual tours, the phenomenological interaction with the place is combined with the act of photographing as a vector of vision, and by channelling vision it provides a purpose and eventually a catalyst for the expression of a sense of place. The tours act as a mobile catharsis and with a conversation taking place in-situ they are also a moment of sociability (Lee and Ingold 2006; Pink 2007, p246) and reflexivity, for both the researcher and the researched, in direct rapport with the physicality they are talking about. This direct rapport allows the participants to expand on points that were only broached during the preliminary in-depth interview. The originality of this approach resides in the physical immersion of both the researcher and the participant. I have principally focused on the rapport to the physicality of place and on how it mattered in terms of social positionality and I have started to consider how it mattered in terms of its incidence on urban and residential mobilities. The discussion must be taken even further and it will be essential to pay even greater conceptual attention to the power-geometries (Massey, 1993; 2005) of mobility in general in the city.

When engaging with this kind of ethnography, I have argued that we must consider four narrative dimensions in the production of sociological knowledge: the 
narrative in the conversation recorded during the tour, but also walking as narrative as well as the narrative of photographs as they are produced and commented upon insitu. Finally, I argue that the voice of the researcher must be considered as an integral part of the process not superimposed but intersecting with the voices of the participants. In understanding sense of place, I have argued that we need to understand it as constructive and constitutive of these intersecting narratives.

\section{Endnotes:} $\mathrm{i}$ 'The word “topophilia” is a neologism, useful in that it can be defined broadly to include all of the human being's
affective ties with the material environment' (Tuan, 1974: 93) 


\section{References:}

AHMED, S. (2000) Strange Encounters: Embodied Others in Post-coloniality.

London: Routledge

BACK, L. (2007) The Art of Listening, Oxford: Berg

BACK, L. (2005) 'Home From Home': youth, belonging and place, in

ALEXANDER, C. and KNOWLES, C (eds), Making Race Matter: bodies, space and identity, Houndmills, Basingstoke: Palgrave Macmillan, pp. 19-41

BANKS, M. (2007) Using Visual Data in Qualitative Research. London: Sage

Publication

BARTHES, R. (1977) [1966] Introduction to the Structural Analysis of Narratives in Image, Music, Text. Essays Selected and Translated by Stephen Heath, London: Fontana, pp. 79-129

BENDINER-VIANI, G. (2005) Walking, Emotion, and Dwelling: Guided Tours in Prospects Heights, Brooklyn, Space and Culture Vol. 8, No. 4, pp. 459-71

BISSELL, D. (2008) Visualising everyday geographies: practices of vision through travel-time, Transactions of the Institute for British Geographers, Vol. 34, pp. 42-60

CASEY, S.C. (1996) How to Get from Space to Place in a Fairly Short Stretch of Time in FELD, S and BASSO, K.H (eds) Senses of Place, Sante Fe (New Mexico): School of American Research Press, pp. 13-52 
CERTEAU, M de. (1984) The Practice of Everyday Life. London: University of California Press

CIERAAD, I. (1999) Dutch Windows: Female Virtue and Female Vice in CIERAAD, I. (ed) At Home: an Anthropology of Domestic Space, New York: Syracuse University Press, pp. 31-52

ELLIOTT, J. (2005) Using Narrative in Social Research: Qualitative and Quantitative Approaches, London: Sage Publications

FINK, J (2012) Walking the Neighbourhood, Seeing the Small Details of Community Life: Reflections from a Photography Walking Tour, Critical Social Policy, Vol. 32, No. 1 , pp. $31-50$

FRANZOSI, R. (1998) Narrative Analysis - Or Why (and how) Sociologists Should Be Interested in Narrative, Annual Review of Sociology, Vol. 24, pp. 517-554

INGOLD, T. (2007) Lines: A Brief History. London: Routledge

GRASSENI, C. (2009) Developing Skills, Developing Vision: practices of locality at the foot of the Alps. Berghahn Books: www.berghahnbooks.com

KARNER, C. (2007) Ethnicity and Everyday Life. London, Routledge 
KEITH, M. (2005) After the Cosmopolitan? Multicultural Cities and the Future of Racism. London: Routledge

KNOWLES, C. (2006) Seeing Race through the Lens, Ethnic and Racial Studies, Vol. 29, No. 3, pp. 512-529

LEE, J. and INGOLD, T. (2006) Fieldwork on Foot: Perceiving, Routing, Socializing in S. Coleman and P. Collins (eds) Locating the Field: Space, Place and Context in Anthropology, Oxford: Berg, pp. 67-85

MASSEY, D. (1993) For Space, London: Sage Publications

MASSEY, D. (1993) Power-geometry and a Progressive Sense of Place. In J. Bird B.

Curtis T. Putman G. Robertson and L. Tickner (eds) Mapping the Futures: Local Cultures and Global Change, London: Routledge, pp. 59-70

MCGARRIGLE, J.L (2010) Understanding Processes of Ethnic Concentration and Dispersal: South Asian Residential Preferences in Glasgow, Amsterdam: Amsterdam University Press

MCGARRIGLE, J.L and KEARNS, A. (2009) Living Apart? Place, Identity and South Asian Residential Choice, Housing Studies, Vol. 24, No. 4, pp. 451-475

MUIR, S. and MASON, J. (2012) Capturing Christmas: The Sensory Potential of Data from Participant Produced Video, In Sociological Research Online, Vol. 17, No. 1 at http://www.socresonline.org.uk/17/1/5.html 
PINK, S. and Mackley, K.L. (2012) Video and a Sense of the Invisible: Approaching Domestic Energy Consumption Through the Sensory Home, In Sociological Research Online, Vol. 17, No. 1 at http://www.socresonline.org.uk/17/1/3.html

PINK, S. (2008) An Urban Tour, The Sensory Sociality of Ethnographic PlaceMaking, Ethnography, Vol. 9, No. 2, pp. 175-196

PINK, S. (2007) Walking with Video, Visual Studies, Vol. 22, No. 3, pp. 240-252

PINK, S. (2004) Home Truths: Gender, Objects and Everyday Life, Oxford: Berg

PHILLIPS, D., Davis, C. and Ratcliffe, P. (2007) British Asian Narratives of Urban Space, Transactions of the Institute of British Geographers, pp. 217-234

PROUST, M. (1987) Du côté de chez Swann, A la Recherche du Temps Perdu (I). Paris:Gallimard

RADLEY, A. (2010) What People do with Pictures, Visual Studies, Vol. 25, No. 3, pp. $268-279$.

RIESSMAN, C.K (2005) Narrative Analysis in Kelly, N. Horrocks, C. Milnes, K.

Robert, B and Robinson, D. Narrative, Memory \& Everyday Life, Huddersfield:

University of Huddersfield, pp.1-7 
TOLIA-KELLY, D.P (2004a) Materializing Post-Colonial Geographies: Examining the Textural Landscapes of Migration in the South Asian Home, Geoforum, Vol. 35, pp. $675-688$

TOLIA-KELLY, D.P (2004b) Locating Processes of Identification: Studying the Precipitates of Re-Memory Through Artefacts in the British Asian Home, Transactions of the Institute of British Geographers Vol. 29, pp. 314-329

TUAN, Y-F. (1974) Topophilia: a Study of Environmental Perception, Attitudes, and Values. London: Prentice-Hall International, Inc.

VERGUNST, J (2010), Rhythms of Walking: History and Presence in a City Street, Space and Culture, Vol. 13, No. 4, pp. 376-388

WILES, R., COFFEY, A., ROBISON, J. and PROSSER, J. (2012) Ethical Regulation and Visual Methods: Making Visual Research Impossible or Developing Good Practice? Sociological Research Online, Vol. 17, No.1, pp. 1-15

WILES, R. PROSSER, J. BAGNOLI, A. CLARK, A. DAVIES, K. ROWLAND, S. and RENOLD, E. (2008) Visual Ethics: Ethical Issues in Visual Research, E.S.R.C National Centre for Research Methods Review Paper, NCRM/011

WISE, A and VELAYUTHAM, S. (2009) Introduction: Multiculturalism and Everyday Life in A. Wise and S. Velayutham (eds) Everyday Multiculturalism, London: Palgrave Mcmillan, pp. 3-17 
